\title{
TRANSIENT BILATERAL VISUAL LOSS PADA PASIEN DENGAN DECOMPRESSION SICKNESS TIPE II
}

\author{
Ida Avu Sri Indrayani ${ }^{1}$, Yenita Khatania Ardjaja ${ }^{2}$, \\ Anak Agung Mas Putrawati Triningrat ${ }^{2}$, Anita Devi ${ }^{3}$
}

\begin{abstract}
${ }^{1}$ Departemen Neurologi, FK Universitas Udayana/RSUP Sangalh Denpasar, Bali, Indonesia
${ }^{2}$ Departemen IImu Kesehatan Mata, FK Universitas Udayana/RSUP Sangalh Denpasar, Bali, Indonesia

${ }^{3}$ Poliklinik Hiperbarik RSUP Sanglah Denpasar, Bali, Indonesia
\end{abstract}

Diterima 25 Maret 2019

Disetujui 25 Maret 2019

Publikasi 28 Maret 2019

Korespondensi: indrayanidayusri@gmail.com
Cara merujuk artikel ini: Sri Indrayani (et al). 2019. Transient bilateral visual loss pada pasien dengan decompression sickness tipe II. Callosum Neurology Journal 2(1): 29-33. DOI: 10.29342/cnj.v2i1.60

\begin{abstract}
ABSTRAK
Latar Belakang: Transient visual loss adalah hilangnya tajam penglihatan mendadak, parsial maupun komplit pada satu atau kedua mata, terjadi kurang dari 24 jam. Decompression sickness terjadi apabila bubble terbentuk saat tubuh mengalami penurunan tekanan ambient secara mendadak.

Kasus: Pasien laki-laki 23 tahun dengan penglihatan kabur mendadak setelah menyelam \pm 5 meter selama 1 me nit. Tajam penglihatan kedua mata pasien saat di rumah sakit adalah 4/60. Pemeriksaan segmen anterior dan posterior kedua mata dalam batas normal. Dilakukan terapi oksigen hiperbarik. Tajam penglihatan kedua mata pasien menjadi $6 / 6$ setelah terapi.
\end{abstract}

Diskusi: Transient bilateral visual loss dengan iskemia oksipital post free diving dicurigai disebabkan sumbatan intravaskular oleh bubble yang terbentuk pada decompression sickness. Terapi oksigen hiperbarik merupakan terapi pilihan.

Simpulan: Pencegahan bubble dalam tubuh adalah dengan menghindari faktor risiko terbentuknya bubble dan mematuhi cara naik ke permukaan (ascending) yang benar setelah penyelaman.

Kata Kunci: Buta mendadak sementara, decompression sickness, penyelam

\section{ABSTRACT}

Background: Transient visual loss is a sudden onset, partial or complete, monocular or binocular visual loss which lasts less than 24 hours. Decompression sickness is caused by bubbles in blood or tissue as sequelae of suddenly reduced ambient pressure on the dissolved inert gases.

Case: A 23 years old man with sudden visual loss while ascending after diving within five meters in depth for one-minute duration. Both visual acuity were $4 / 60$. Anterior and posterior segment of both eyes were with in normal limit. Visual acuity in both eyes were $6 / 6$ after hyperbaric therapy.

Conclusion: Preventing bubble formation is to avoid the risk factor and obey the ascending rule of diving.

Discussion: Transient bilateral visual loss was caused by gas bubbles that inhibits the blood flow. Hyperbaric oxygen the rapyis the treatme nt of choice.

Keywords: transient visual loss, decompression sickness, diver 


\section{Latar Belakang}

Transient visual loss adalah hilangnya tajam penglihatan mendadak baik parsial maupun komplit pada satu atau kedua mata yang terjadi kurang dari 24 jam. ${ }^{1} \quad$ Transient visual loss dapat disebabkan oleh gangguan aliran darah ke mata atau visual pathway yang bersifat sementara, atau adanya lesi pada komponen retinokortikal dari visual pathway. Transient visual loss dapat terjadi pada satu mata (monocular) atau kedua mata (binocular). Transient bilateral visual loss disebabkan oleh lesi di chiasma, postchiasma, atau bilateral prechiasma. ${ }^{2,3}$ Penyebab transient bilateral visual loss yang paling sering adalah migren, massa di daerah occipital, iskemia daerah occipital, dan occipital seizure. ${ }^{1}$

Decompression sickness terjadi apabila gelembung gas (bubble) yang terbentuk pada saat tubuh mengalami penurunan tekanan ambient secara mendadak pada pembuluh darah (intravaskular), sistem muskuloskeletal, atau jaringan tubuh lainnya menimbulkan suatu gejala. Bubble di intravascular dapat mengakibatkan obstruksi vaskular, menghambat aliran darah dan menyebabkan iskemia. ${ }^{4,5}$ Iskemia pada daerah occipital akan menyebabkan terjadinya transient bilateral visual loss. ${ }^{1}$

Terapi oksigen hiperbarik adalah terapi yang menggunakan oksigen dengan menyediakan lingkungan bertekanan dimana pasien menghirup oksigen $100 \%$ secara intermiten. Terapi oksigen hiperbarik harus dilakukan pada semua pasien dengan keluhan hilangnya tajam penglihatan dengan riwayat terpapar lingkungan hiperbarik atau kondisi unpressurized high-altitude. Semua pasien setelah dilakukan terapi oksigen hiperbarik harus dilakukan evaluasi oleh dokter spesialis mata. ${ }^{6}$

\section{Laporan Kasus}

Pasien laki-laki berusia 23 tahun pertama kali datang pada tanggal 10 April 2014 ke UGD RSUP Sanglah ke bagian neurologi dengan keluhan penglihatan kabur yang terjadi mendadak kurang lebih satu jam sebelum datang ke rumah sakit. Penglihatan kabur dikeluhkan setelah pasien naik ke permukaan dari kegiatan menyelam sedalam kurang lebih lima meter selama 1 menit. Penglihatan kabur dikatakan hingga pasien hanya dapat melihat gerakan benda bergoyang. Pasien saat itu menyelam dan naik ke permukaan dengan cepat. Keluhan penglihatan kabur setelah itu disertai dengan nyeri kepala. Nyeri kepala dikatakan seperti berdenyut. Riwayat penggunaan kacamata, trauma, kelemahan atau kesemutan separuh tubuh, suara pelo, pusing berputar, sesak nafas, dan gangguan buang air disangkal. Pasien mengatakan sedang flu saat melakukan diving. Pasien bekerja sebagai snorkeling guide selama dua tahun. Pasien memiliki kebiasaan menarik napas cepat dan dalam beberapa kali sebelum melakukan free diving.

Pemeriksaan dari neurologi mendapatkan visus mata kanan dan kiri (ODS) 4/60. Diagnosis dari bagian neurologi adalah Sudden blindness et causa decompression sickness type II + cephalgia yang berkaitan dengan trauma kepala lainnya (barotrauma). Pemeriksaan darah lengkap menunjukkan dalam batas normal. Pasien diberikan rehidrasi dengan $\mathrm{NaCl} 0,9 \%$, steroid, gastroprotektan, analgetik, neuroprotektor. Pemeriksaan dari bagian mata mendapatkan visus pada mata kanan dan kiri (ODS) 4/60 dengan pinhole not improve (NI). Gerak bola mata kanan dan kiri baik ke segala arah. Pemeriksaan segmen anterior ODS didapatkan dalam batas normal, relative afferent pupillary defect (RAPD) negatif dan segmen posterior dalam batas normal. Tekanan intraokuli didapatkan pada OD $12 \mathrm{mmHg}$ dan OS $14 \mathrm{mmHg}$. Pasien didiagnosis dengan ODS sudden visual loss. Pencitraan CT-scan dan rontgen thoraks dalam batas normal. Pemeriksaan fundus tidak ditemukan kelainan (Gambar 1). Pemeriksaan lapangan pandang mata kanan dan kiri tidak ada kelainan (Gambar 2 dan 3).
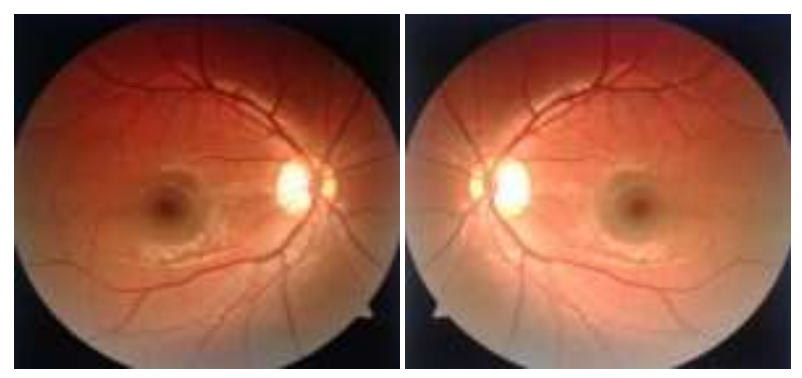

Gambar 1. Foto fundus mata kanan dan kiri

Bagian neurologi mengkonsulkan pasien ke bagian hiperbarik. Pasien didiagnosis shallow water blackout dengan diagnosis banding decompression illness. Dilakukan satu kali terapi oksigen hiperbarik dengan pemberian oksigen $100 \%$ pada kedalaman 18 meter (2.8 ATA) selama 120 menit.

Pemeriksaan di poli mata setelah dilakukan terapi oksigen hiperbarik didapatkan visus ODS 6/6, segmen anterior dan posterior dalam batas normal. Pemeriksaan Ishihara dan Farnsworth 15D ODS normal. Pemeriksaan sensitivitas kontras ODS adalah 1.65. Pasien didiagnosis dengan ODS transient bilateral visual loss. Pasien diijinkan pulang dan rencana kontrol satu minggu tetapi pasien tidak datang. 


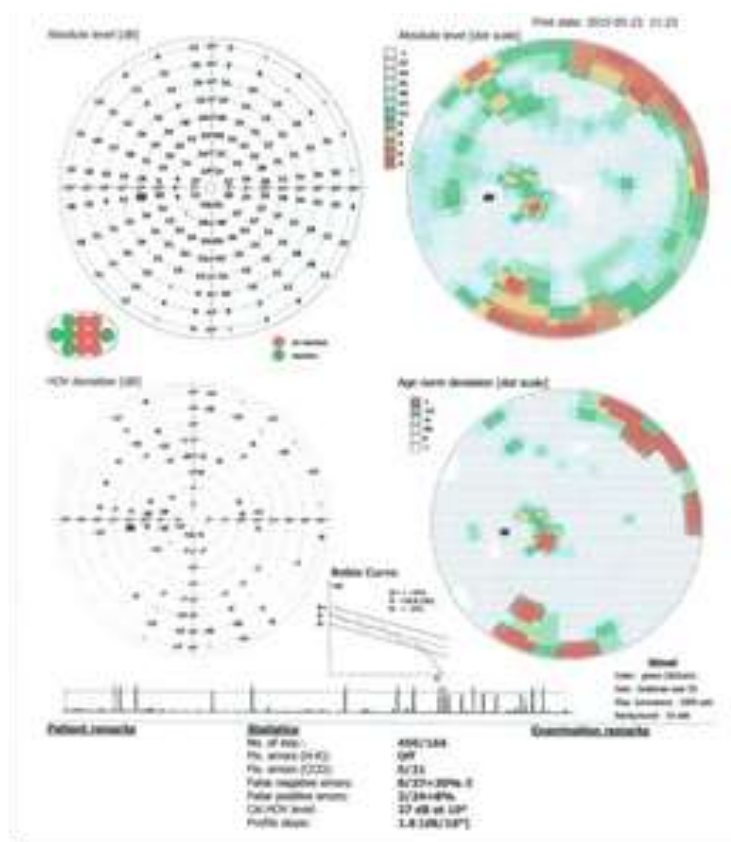

Gambar 2. Pemeriksaan lapang pandang mata kanan menunjukkan tidak ada defek.

Diagnosis dari bagian neurologi adalah sudden blindness et causa decompression sickness type II dengan diagnosis banding shallow water blackout. Pasien diijinkan pulang dari bagian neurologi dan direncanakan untuk kontrol dalam satu minggu.

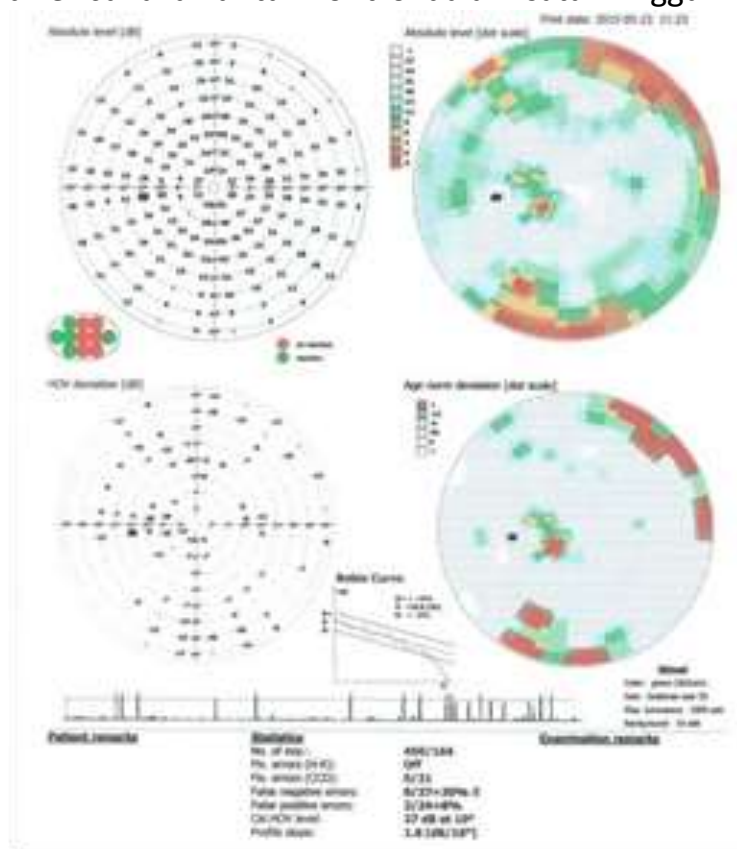

Gambar 3. Pemeriksaan lapang pandang mata kiri menunjukkan tidak ada defek.

\section{Diskusi}

Decompression sickness terjadi apabila gelembung gas yang terbentuk pada saat tubuh mengalami penurunan tekanan ambient secara mendadak pada pembuluh darah, sistem muskuloskeletal, atau jaringan tubuh lainnya menimbulkan suatu gejala. Faktor risiko terjadinya decompression sickness antara lain kedalaman dan durasi menyelam, usia tua, kadar lemak dalam tubuh yang tinggi, olahraga sebelum melakukan diving, suhu dingin, kondisi tubuh yang tidak sehat, riwayat minum minuman beralkohol dan kecepatan naik ke permukaan. ${ }^{4,5}$

Pasien mengatakan sedang flu saat melakukan diving, kondisi air saat menyelam adalah dingin, dan pasien naik ke permukaan dengan cepat. Hal tersebut meningkatkan risiko terjadinya decompression sickness.

Bubble yang terbentuk dalam tubuh terjadi karena kecepatan penurunan tekanan ambient secara mendadak melebihi kecepatan pembuangan inert gas dari jaringan. Bubble pada decompression sickness memiliki efek mekanik, embolik, dan biokimia dengan manifestasi klinis bervariasi mulai dari ringan hingga fatal. Manifestasi klinis pada decompression sickness dapat disebabkan oleh efek langsung bubble di ekstravaskular yang dapat menyebabkan nyeri, atau obstruksi vaskular yang menyebabkan gejala tergantung lokasi penyumbatan oleh bubble. Kerusakan endotel yang disebabkan oleh bubble intravaskular dapat menyebabkan kebocoran kaliper, ekstravasasi plasma, dan hemokonsentrasi. ${ }^{5}$ Pada pasien ini didapatkan nyeri kepala dan penurunan tajam penglihatan dicurigai karena efek dari bubble di intravaskular yang menyebabkan obstruksi sehingga suplai darah ke daerah occipital berkurang dan menyebabkan terjadinya iskemia di daerah oksipital.

Decompression sickness terbagi menjadi dua tipe.

Tipe satu (I) terbatas pada kulit, muskuloskeletal, dan sistem limfatik. Tipe dua (II) meliputi sistem saraf, jantung, dan paru.4,5 Gangguan visual adalah gejala yang paling sering dikeluhkan pada neurological decompression sickness. Lima dari 16 pasien dengan decompression sickness mengalami penurunan tajam penglihatan. ${ }^{7}$ Gejala neurologi akut pada semua pasien dengan riwayat menyelam harus dicurigai sebagai decompression sickness. ${ }^{6}$ Pada kasus ini pasien mengalami gejala hilangnya tajam penglihatan dan nyeri kepala setelah melakukan kegiatan menyelam menunjukkan gejala neurologi sehingga didiagnosis dengan decompression sickness tipe II.

Diagnosis decompression sickness ditegakkan secara klinis dengan anamnesis yang akurat. Diagnosis decompression sickness dapat dipastikan apabila gejala yang dialami pasien membaik setelah dilakukan terapi rekompresi. $^{7}$ 
Pasien menunjukkan perbaikan tajam penglihatan setelah dilakukan terapi rekompresi sehingga diagnosis decompression sickness dapat ditegakkan.

Shallow water blackout merupakan diagnosis banding dari decompression sickness. Terminologi shallow water blackout biasanya digunakan untuk mendeskripsikan hilangnya kesadaran akibat tidak adekuatnya asupan oksigen ke otak pada saat menahan napas di dalam air sedalam lima meter atau kurang. ${ }^{8,9}$ Dari anamnesis didapatkan pasien menyelam sedalam kurang lebih lima meter selama satu menit dan mengalami "blackout" dan dari anamnesis didapatkan pasien melakukan hiperventilasi sebelum free diving sehingga shallow water blackout menjadi diagnosis banding pada kasus ini.

Pada penyelaman, hiperventilasi dapat berarti bernafas secara cepat dan dalam melebihi kebutuhan untuk beraktifitas. Para penyelam melakukan hiperventilasi secara tidak sadar pada kondisi stres yang tinggi dengan riwayat penyakit sebelumnya dan secara sadar dilakukan oleh free diver untuk memperpanjang waktu menahan napas. Shallow water blakcout dapat disebabkan oleh banyak faktor. Hiperventilasi adalah salah satu penyebab terjadinya hipoksia pada orang yang menahan napas di dalam air. ${ }^{8}$ Dari anamnesis didapatkan pasien menarik napas dalam sebelum menyelam dengan tujuan untuk mengambil oksigen lebih banyak agar dapat lebih lama bertahan di dalam air.

Sebelum melakukan free diving, para penyelam melakukan hiperventilasi sehingga menyebabkan terjadinya penurunan $\mathrm{CO} 2$ dalam tubuh. Rendahnya kadar CO2 yang abnormal akan memberikan tambahan waktu untuk menyelam sebelum kadar CO2 cukup tinggi untuk memberikan suatu stimulus dalam menarik napas. Selama proses menyelam, $\mathrm{O} 2$ terus terpakai dan mencapai kadar yang sangat rendah yang dapat menyebabkan terjadinya hipoksia. ${ }^{9}$

Transient bilateral visual loss terjadi pada kedua mata dalam waktu kurang dari 24 jam. ${ }^{1}$ Pada kasus ini, pasien mengatakan hanya bisa melihat lambaian tangan sesaat setelah naik ke permukaan air, dapat melihat hitungan jari dalam jarak empat meter saat tiba di rumah sakit, dan menjadi 6/6 setelah mendapat terapi rekompresi dalam waktu kurang dari 24 jam.

Transient bilateral visual loss disebabkan oleh lesi di chiasma, postchiasma, atau bilateral prechiasma. Penyebab transient bilateral visual loss yang paling sering adalah migraine, massa di daerah oksipital, iskemia daerah oksipital, dan occipital seizure. ${ }^{1,10}$ Iskemia otak di daerah occipital diyakini sebagai penyebab transient bilateral visual loss yang terjadi pada kasus ini.

Pemberian steroid diindikasikan pada pasien dengan decompression sickness berat apabila terapi rekompresi tidak dapat dilakukan segera. Steroid dapat menstabilkan endotel vaskular dan memiliki efek antiedema. ${ }^{7}$ Pada pasien ini diberikan steroid oleh bagian neurologi atas dasar diagnosis decompression sickness tipe II dan pada kasus ini tidak dapat dilakukan terapi rekompresi segera dengan terapi oksigen hiperbarik.

Terapi oksigen hiperbarik adalah terapi pemaparan oksigen $100 \%$ secara intermiten pada tekanan lebih dari satu atmosphere absolute (ATA). ${ }^{12}$ Terapi oksigen hiperbarik memiliki efek fisiologik dan mekanik dengan cara menginduksi peningkatan tekanan dan hiperoksia. ${ }^{13}$

Terapi oksigen hiperbarik bekerja dengan cara meningkatkan konsentrasi dissolved oxigen di darah dan meningkatkan perfusi, merangsang pembentukan matriks kolagen, mengganti gas inert pada aliran darah dengan oksigen dan dimetabolisme, dan bekerja sebagai bakterisidal. Setiap terapi dilaksanakan antara 60 hingga 120 menit. ${ }^{14}$ Terapi oksigen hiperbarik juga memiliki beberapa keuntungan yaitu meningkatkan oksigenasi jaringan, mengurangi edema pada central nervous system, dan menghambat akumulasi leukosit pada endotel pembuluh darah. ${ }^{15}$ Pada kasus ini terapi oksigen hiperbarik dilakukan untuk meningkatkan perfusi dan oksigenasi ke otak terutama daerah occipital, mengganti gas inert pada aliran darah dengan oksigen, dan menghambat akumulasi leukosit pada endotel pembuluh darah. Indikasi dilakukannya terapi oksigen hiperbarik adalah hilangnya tajam penglihatan yang terjadi dalam 24 jam, tajam penglihatan dengan pinhole atau setelah dikoreksi tetap 20/200 atau lebih buruk, usia lebih dari 40 tahun, penurunan tajam penglihatan tanpa disertai rasa nyeri, tidak terdapat riwayat floaters atau kilatan cahaya sebelum tajam penglihatan menurun, dan tidak terdapat riwayat operasi atau trauma pada mata. Terapi oksigen hiperbarik harus dilakukan apabila keluhan hilangnya tajam penglihatan berhubungan dengan riwayat terpapar lingkungan hiperbarik atau kondisi unpressurized high-altitude. Semua pasien setelah dilakukan terapi oksigen hiperbarik harus dilakukan evaluasi oleh dokter spesialis mata. ${ }^{6}$ Pasien pada kasus ini mengalami penurunan tajam penglihatan segera setelah menyelam selama satu menit pada kedalaman lima meter. Hal tersebut merupakan indikasi dilakukan terapi oksigen hiperbarik pada pasien ini. 
Terapi rekompresi terdiri dari beberapa tabel. Terapi inisial dimulai pada kedalaman 18 meter (tekanan 2.8 ATA). Oksigen sebanyak 100\% dapat diberikan tanpa menyebabkan toksisitas pada tekanan 2.8 ATA. ${ }^{15}$ Pada kasus ini, pasien diberikan terapi oksigen hiperbarik sesuai dengan protokol pada US Navy Table 5 (Royal Navy Table 61), yaitu pasien diberikan oksigen $100 \%$ selama total waktu 120 menit dimulai pada kedalaman 18 meter $(2,8$ ATA) dan perlahan - lahan naik ke permukaan. Setelah satu kali terapi, gejala yang dialami pasien hilang dan tajam penglihatan membaik menjadi $6 / 6$.

\section{Daftar Rujukan}

1.American Academy Ophthalmology. 2014. The patient with transient visual loss. In: AAO Staff (eds).Neuroophthalmology. BCSC Section 11. San Fransisco: AAO; p. 161-172

2.Sandhya N. 2010. Transient visual loss. Kerala journal of ophthalmology 22(2); 167-73

3.Gopwani J, Margolin E. 2014. Transient visual obscuration clues to localization. Ophthalmology rounds;10(8)

4.Verma R. 2012. A case of decompression illness during saturation diving. MJAFI (68); 185-6

5.Vann RD, Bulter FK, Mitchell SJ, et al. 2010.Decompression Illness. Lancet (377); 15364

6.Butler FK, Hagan C, Muprhy-Lavoie H. 2008. Hyperbaric oxigen therapy and the eye. UHM 35(5); 327-81

7.Moon RE. 1998. Assessment of patient with decompression illness. South Pasific Underwater Medicine Society Journal 28 (1); 23-8

8.Quan L, Culver BH, Fielding RR. 2010. HypoxiaInduced loss of consciousness in multiple synchronized swimmers during a Workout. International Journal of Aquatic Research and Education (4); 379-389

9.Taylor L. 2002. Shallow water blackout. Available at: www.nzunderwater.org.nz. Accessed on May, 15th 2015

10.Gopwani J, Margolin E. 2014. Transient visual obscuration clues to localization. Ophthalmology rounds;10(8)

11.Carlston CB, Mathias RA, Shilling CW. 2012. Immediate evaluation of the diving casualty. In: Kent MB (ed). The physician's guide to diving medicine. New York: Springer; p. 273-80

12.Thackham JA, McElwain DLS, Long RJ. 2007. The use of hyperbaric oxygen therapy to treat chronic wounds: a review. Wound Repair Reg (16): 321-330

\section{Simpulan}

Kasus transient bilateral visual loss pada pasien post free diving dapat disebabkan oleh iskemia daerah occipital yang dapat terjadi karena oklusi vaskular oleh bubble yang terbentuk pada decompression sickness. Mencegah terbentuknya bubble dalam tubuh adalah dengan menghindari faktor risiko terbentuknya bubble dan mematuhi cara naik ke permukaan (ascending) yang benar setelah diving. Terapi oksigen hiperbarik merupakan terapi pilihan pada pasien dengan pada pasien dengan riwayat terpapar lingkungan hiperbarik atau kondisi unpressurized high-altitude.

13.McDonagh M, Carson S, Ash J, et al. 2003. Hyperbaric Oxygen Therapy for Brain Injury, Cerebral Palsy, and Stroke. In: Evidence Report/Technology Assessment (85). Rockville, MD: Agency for Healthcare Research and Quality.

14.Brown JG. 2000. Hyperbaric oxygen therapy: Its use and appropriateness. In: OEI Regional VI Report. USA: Office of Inspector General, Department of Health and Human Services

15.Antonelli C, Franchi F, Marta MED, et al. 2009. Guiding principles in choosing a therapeutic table for $\mathrm{DCl}$ hyperbaric therapy. Minerva Anestesiol (75); 151-61. 
